\title{
Effect of Tryptophan on Growth and Morphology of Hansenula schneggii Cells
}

\author{
MALEE SUNDHAGUL AND L. R. HEDRICK \\ Biology Department, Illinois Institute of Technology, Chicago, Illinois
}

Received for publication 28 January 1966

\begin{abstract}
Sundhagul, Malee (Illinois Institute of Technology, Chicago), AND L. R. HedRICK. Effect of tryptophan on growth and morphology of Hansenula schneggii cells. J. Bacteriol. 92:241-249. 1966.-When Hansenula schneggii cells were cultured aerobically in a tryptophan-glucose medium, 70 to $90 \%$ of the cells were elongated; no growth occurred under anaerobic conditions. The size of the elongated cells was 15 to $25 \mu$ by 2 to $4 \mu$, as compared with 2.5 to $5 \mu$ for ellipsoidal cells. Formation of elongated cells occurred essentially during the logarithmic growth period; the highest percentage of elongated cells was found soon after the end of this growth phase. In the later stationary phase, some of the cells formed spherical buds which became spherical cells. The rate of cell division during this period was greatly reduced, but the spherical cells formed decreased the percentage of elongated cells in the population. Cells cultured in a membrane-filter filtrate of a tryptophan-glucose medium (with limiting tryptophan), in which elongated cells had been grown, were ellipsoidal until nitrogenous nutrients were exhausted; thereafter the cells were elongated if tryptophan was added. Of compounds related to tryptophan, kynurenine was the only one which induced a high percentage of the cells to elongate. Some amino acids, such as cystine, histidine, phenylalanine, tyrosine, and threonine, induced elongation in about $15 \%$ of the cells. Growth of cells with other amino acids, or the addition of most of the other amino acids to tryptophan-glucose medium, resulted in a population of spherical cells. Several consecutive sequential transfers of cells into tryptophan medium induced elongation in $90 \%$ of the cells, but one transfer from a culture with elongated cells into a medium with ammonium sulfate, or a mixture of amino acids, gave a culture with ellipsoidal cells. Growth in media at $p \mathrm{H} 4$ or 5 favored formation of elongated cells; as the $p \mathrm{H}$ was increased, the percentage of elongated cells decreased. Carbon sources other than glucose did not affect the percentage of elongated cells, except for the alcohols mannitol and erythitol, which gave comparable growth but reduced the percentage of elongated cells from 70 to $50 \%$. Cell wall analyses of the two types of cells indicated that elongated cells have 2.5 times as much mannan as cell walls of ellipsoidal cells. This suggests that tryptophan, kynurenine, and, to a limited extent, some of the other amino acids cause a diversion of polysaccharide biosynthesis to mannan in the elongated cells rather than to glucan as in ellipsoidal cells.
\end{abstract}

Most of the reports with respect to morphogenesis of yeasts and fungi have been made by Nickerson and his co-workers. They have reported on yeast-form to filament conversion $(7,16)$, the effect of carbon dioxide (3), change of cell population of Trigonopsis variabilis from mostly ellipsoidal to mostly triangular by growth in methionine $(24,25)$, and the basis of morphogenesis (15). Yanagishima (29) reported that $63 \%$ of the cells of Saccharomyces cerevisiae were elongated when grown in a medium containing a mixture of several nitrogen sources ( $\mathrm{L}$-asparagine,
L-leucine, L-arginine, L-glutamate, and ammonium sulfate) with $2 \%$ maltose as a carbon source. Removal of these nitrogen sources from the medium, one at a time, decreased the percentage of elongated cells; deletion of L-asparagine reduced elongation to $6 \%$, and removal of $\mathrm{L}$-leucine decreased elongation to $1 \%$. Yanagishima and Masauda (30), in a study of yeast elongation with the aid of the auxin gibberellic acid, have implicated a compound similar to ribonucleic acid (RNA) as an agent in elongation; removal of RNA with ribonuclease prevented yeasts from 
responding to the auxin. In both of these studies, the amount of elongation was only 1 to $3 \mu$.

In studies of the utilization of single amino acids as a sole nitrogen source by species of Hansenula yeasts, it was observed that a large percentage of $\boldsymbol{H}$. schneggii cells, when grown with tryptophan as a nitrogen source, became greatly elongated with a length of 15 to $20 \mu$. These cells were found either singly or as chains, but were not typical fungal filaments. Cells grown in a defined medium with most other single amino acids, with ammonium sulfate, or with YM broth or casein hydrolysate as a nitrogen source, consisted of ellipsoidal cells with a length of about 5 to $6 \mu$ and a diameter of 2.5 to $4 \mu$.

This report is concerned with several of the factors related to elongation of cells of $H$. schneggii when cultured in a defined medium with tryptophan as a nitrogen source and glucose or amino acids other than tryptophan as a carbon source.

\section{Materials AND Methods}

The yeast used in this study was $H$. schneggii (Weber) Dekker, NRRL strain Y 993. Stock cultures were maintained on YM agar slants. This medium has the following composition (grams per liter): glucose, 10; peptone, 5; yeast extract, 3 ; malt extract, 3 ; and agar, 20. The cultural and physiological characteristics of the culture were checked at periodic intervals during the course of the investigation and at all times agreed with those for the standard description of the species.

In experimental studies, a defined basal medium was employed with different nitrogen sources. The basal medium consisted of a solution of salts (28) plus $20 \mathrm{~g}$ of glucose per liter. The different nitrogen sources with their respective concentrations were (i) $\left(\mathrm{NH}_{4}\right)_{2} \mathrm{SO}_{4}, 3.0 \mathrm{~g}$ per liter; (ii) casein hydrolysate (Sheffield's HyCase-salt free), $3.0 \mathrm{~g}$ per liter; and (iii) single L-amino acids, $300 \mu \mathrm{g}$ of $\mathrm{N}$ per ml. A medium extensively used throughout the study was the tryptophan-glucose-salts (TG) medium. The $p \mathrm{H}$ of the media was adjusted to 5.0 with $0.1 \mathrm{~N} \mathrm{NaOH}$. Glucose and ammonium sulfate were sterilized separately by autoclaving at $120 \mathrm{C}$ for $15 \mathrm{~min}$; solutions of amino acids and related compounds were sterilized by the use of a Seitz filter or a membrane filter with a pore size of $0.45 \mu$. All of these ingredients were added in appropriate amounts to the basal medium to make $10-\mathrm{ml}$ quantities of medium in $18-\mathrm{mm}$ test tubes or in larger quantities in flasks.

Cells used for the inoculation of the different media were cultured for $48 \mathrm{hr}$ at $28 \mathrm{C}$ in glucose-ammonium sulfate-salts medium without any added vitamins, since this yeast does not require added vitamins.

The cells were harvested by centrifugation and washed three times with sterile distilled water. Depleted cells were prepared by shaking washed cells overnight at $28 \mathrm{C}$ in $0.001 \mathrm{M}$ phosphate buffer $(p \mathrm{H}$ 7.0) containing $0.5 \%$ glucose to remove most of their nitrogen reserves. Cells separated from the buffer by centrifugation were washed twice and were suspended in sterile water to give an optical density (OD) of 0.350 at $610 \mathrm{~m} \mu$. A $0.1-\mathrm{ml}$ amount of this suspension, when added to each tube with $10 \mathrm{ml}$ of growth medium, gave an initial OD of 0.06 . The cells were then incubated at $28 \mathrm{C}$ for $72 \mathrm{hr}$ on a New Brunswick rotary shaker with a speed of $180 \mathrm{rev} / \mathrm{min}$.

The amount of growth during the incubation period was determined by the increase in OD at $610 \mathrm{~m} \mu$ with a Coleman model 14 spectrophotometer; the uninoculated medium was used as a blank. Cell length and diameter were measured for 150 to 250 cells in each culture when there was evidence of cell elongation.

Cells for cell wall determinations were separated from the growth medium by a Servall continuous-flow centrifuge. The cells were washed three times with distilled water and were broken by shaking in a flask with glass beads at $4 \mathrm{C}$ for two 5 -hr periods. Cells were washed with cold water 10 times after each 5-hr period. Unbroken cells and larger fragments were removed from the suspended sediment by centrifugation at $800 \times g$ with $0.2 \mathrm{M}$ sucrose for $15 \mathrm{~min}$. The principal cell wall fragments were recovered by centrifugation at 1,500 and at $2,500 \times g$ for $30 \mathrm{~min}$. These were combined and washed exhaustively (10 times) with distilled water. Examination under a microscope indicated that contamination with intracellular particles was negligible. The cell wall material was lyophilized and stored at $4 \mathrm{C}$ in a stoppered vial.

Total nitrogen was determined by the micro-Kjeldahl method of Kemmerer and Hallet (11) and Kabat and Mayer (10). Protein measurements were made by a procedure of Lowry et al. (12) with crystallized bovine serum albumin as a standard. Tryptophan was determined by the method of Spies and Chambers (26). Proline was estimated by the method of Piez et al. (19).

For amino acid determination other than tryptophan, the cell walls were hydrolyzed with $6 \mathrm{~N}$ hydrochloric acid for $24 \mathrm{hr}$ at $100 \mathrm{C}$ in a sealed tube; for tryptophan, they were hydrolyzed with alkali. The amino acids were separated and estimated by the two-dimensional paper chromatography method of Roberts et al. (20) and Meyer (14) with phenolwater-ammonia $(80: 20: 10)$ as solvent in one direction and butanol-acetic acid-water $(2: 1: 2)$ as solvent in the other direction. Total soluble amino nitrogen was determined by the ninhydrin method of Rosen (22).

Deoxyribonucleic acid (DNA) was determined by the diphenylamine reaction used by Burton (4). Standard DNA solutions were prepared from highly polymerized calf thymus obtained from Nutritional Biochemicals Corp., Cleveland, Ohio. RNA was estimated by the orcinol reaction as described by Schneider (23). Standard RNA solutions were prepared from yeast ribonucleic acid purchased from Nutritional Biochemicals Corp.

Mannan was estimated by extracting $100 \mathrm{mg}$ of dry cell walls with two $20-\mathrm{ml}$ portions of $2 \% \mathrm{NaOH}$ for $30 \mathrm{~min}$ at $100 \mathrm{C} \mathrm{(21).} \mathrm{The} \mathrm{undissolved} \mathrm{residue} \mathrm{was}$ washed twice with $2 \mathrm{ml}$ of alkali; these washings were combined with the two extracts. These solutions were cooled at $4 \mathrm{C}$, and an excess of cold Fehling's solution was added to precipitate mannan in the cold. This 
precipitate was washed three times with distilled water and dried. A 50-mg amount of the dry precipitate was dissolved in $20 \mathrm{ml}$ of $2 \mathrm{~N} \mathrm{HCl}$ and hydrolyzed by heating in a boiling-water bath for $30 \mathrm{~min}$. This solution was cooled and neutralized with $\mathrm{KOH}$ and diluted so that $1 \mathrm{ml}$ contained about $1 \mathrm{mg}$ of carbohydrate. Paper chromatograms of this solution, made by the method of Partridge (18), showed that mannan was the only carbohydrate present. Quantitative determinations of mannan were made with the anthrone reagent, with the use of a correction factor of 0.55 , according the method of Dimler et al. (5) and Eaton (6).

Lipids were quantitatively measured by the method of Al-Doory and Larsh (2). Phosphorus was determined by the method of Fiske and SubbaRow (8).

\section{RESULTS}

Cell elongation by growth in tryptophan. Cells of $H$. schneggit were found to use 18 amino acids, including tryptophan, as a source of nitrogen; cysteine was not so utilized. When glucose was omitted from the tryptophan medium, the separate addition of amino acids ( $300 \mu \mathrm{g}$ of $\mathrm{N}$ per $\mathrm{ml}$ ) such as alanine, arginine, aspartic acid, glutamic acid, proline, and, to a lesser extent, leucine and isoleucine, supplied the carbon. Many of the cells grown with tryptophan as a nitrogen source were greatly elongated. The number of elongated cells after $72 \mathrm{hr}$ of incubation depended in part upon the inoculum: with an inoculum of depleted cells, $75 \%$ of the cells were elongated; with an inoculum of nondepleted cells, 50 to $60 \%$ of the cells were elongated. The dimensions of the elongated cells were 15 to $25 \mu$ by 2 to $4 \mu$; the dimensions of the ellipsoidal cells were 2.5 to $4 \mu$ by 5 to $6 \mu$. Figure 1 illustrates the cell shape and size for both elongated and ellipsoidal cells. The $L$ and racemic mixture of $D$ and $L$ isomers of tryptophan gave equal amounts of growth and elongation, provided that equivalent quantities of the $\mathrm{L}$ form were supplied; no growth occurred with D-tryptophan. The L-tryptophan concentration required for maximal growth and highest percentage of elongation was $120 \mu \mathrm{g}$ of $\mathrm{N}$ per $\mathrm{ml}$; $60 \mu \mathrm{g}$ of $\mathrm{N}$ per ml gave slightly less growth with the same percentage of elongated cells. Tryptophan was the only amino acid used as a sole source of nitrogen which caused a high percentage of the cells to be elongated. The only other amino acids used as a source of nitrogen which caused some of the cells to be elongated were cystine, histidine, phenylalanine, tyrosine, and threonine; all of these caused elongation of 12 to $15 \%$ of the cells.

Ammonia and most of the other amino acids were more readily used as a nitrogen source than was tryptophan. This was established by following the uptake of tryptophan in the presence of other nitrogen sources and determining the assimilation rates with radioactive amino acids. When some other nitrogen sources were added separately at a concentration of $100 \mu \mathrm{g}$ of $\mathrm{N}$ per $\mathrm{ml}$ to the TG medium, the percentage of elongated cells was much lower than for cells grown in the TG medium. For instance, some nitrogen sources tested in this way gave the following percentages of elongated cells: aspartic acid, $4 \%$; cystine, $12 \%$; histidine, $10 \%$; methionine, $3 \%$; phenylalanine, $4 \%$; ammonium sulfate, $2 \%$; and casein hydrolysate, $1.5 \%$. Cells cultured in a glucose-free tryptophan medium with other amino acids (such as alanine, glutamic acid, or proline) as sources of carbon, and of most of the nitrogen, were essentially all ellipsoidal.

Relative numbers of elongated cells were determined for a series of eight experiments in which the amount of tryptophan was constant and the amount of proline was varied. As the amount of proline was increased, the percentage of elongated cells decreased (Fig. 2); the additional growth in the tubes with added proline was due to the utilization of proline carbon.

Six strains of $\boldsymbol{H}$. anomala, a species rather closely related to $H$. schneggii, were grown in the TG medium, but none of them formed elongated cells; these strains were $Y 365, Y 366$, Y 366-8, Y 1656, Y 1737, and Y 2154-4. No other species of yeast tested were positive for this character; the species examined were: $\boldsymbol{H}$. capsulata Y 1889, $H$. holstii $Y$ 2154, $H$. minuta Y 411, H. saturnus Y 1304, H. suaveolens Y 1725, and $S$. cerevisiae Y 239.

Growth of cells. For experiments to determine the percentage of elongated cells during different phases of growth, culture media in conical flasks with side arms were inoculated with depleted or nondepleted cells and were incubated on a shaker for $72 \mathrm{hr}$ at $28 \mathrm{C}$. Two types of media were used: ammonium-glucose-salts (AG) and TG medium. The response in the TG medium with depleted cells as an inoculum was characterized by a much longer lag period, less total growth, and a larger percentage of elongated cells when compared with the response of the culture inoculated with nondepleted cells (Fig. 3). Quantitative estimates of the ninhydrin-positive substances in the inoculum suspension showed that $1 \mathrm{ml}$ of nondepleted cell suspension contained $30.2 \mu \mathrm{g}$ of these materials versus $3.0 \mu \mathrm{g}$ for $1 \mathrm{ml}$ of depleted cells; therefore, when $0.6 \mathrm{ml}$ of inoculum was used for $60 \mathrm{ml}$ of medium in each flask, 18.0 and $1.8 \mu \mathrm{g}$ of ninhydrin-positive substances were added with the respective inocula. This difference of $16.2 \mu \mathrm{g}$ of ninhydrin-positive compounds was the major factor, if not the only one, responsible for a corresponding reduction in the percentage 


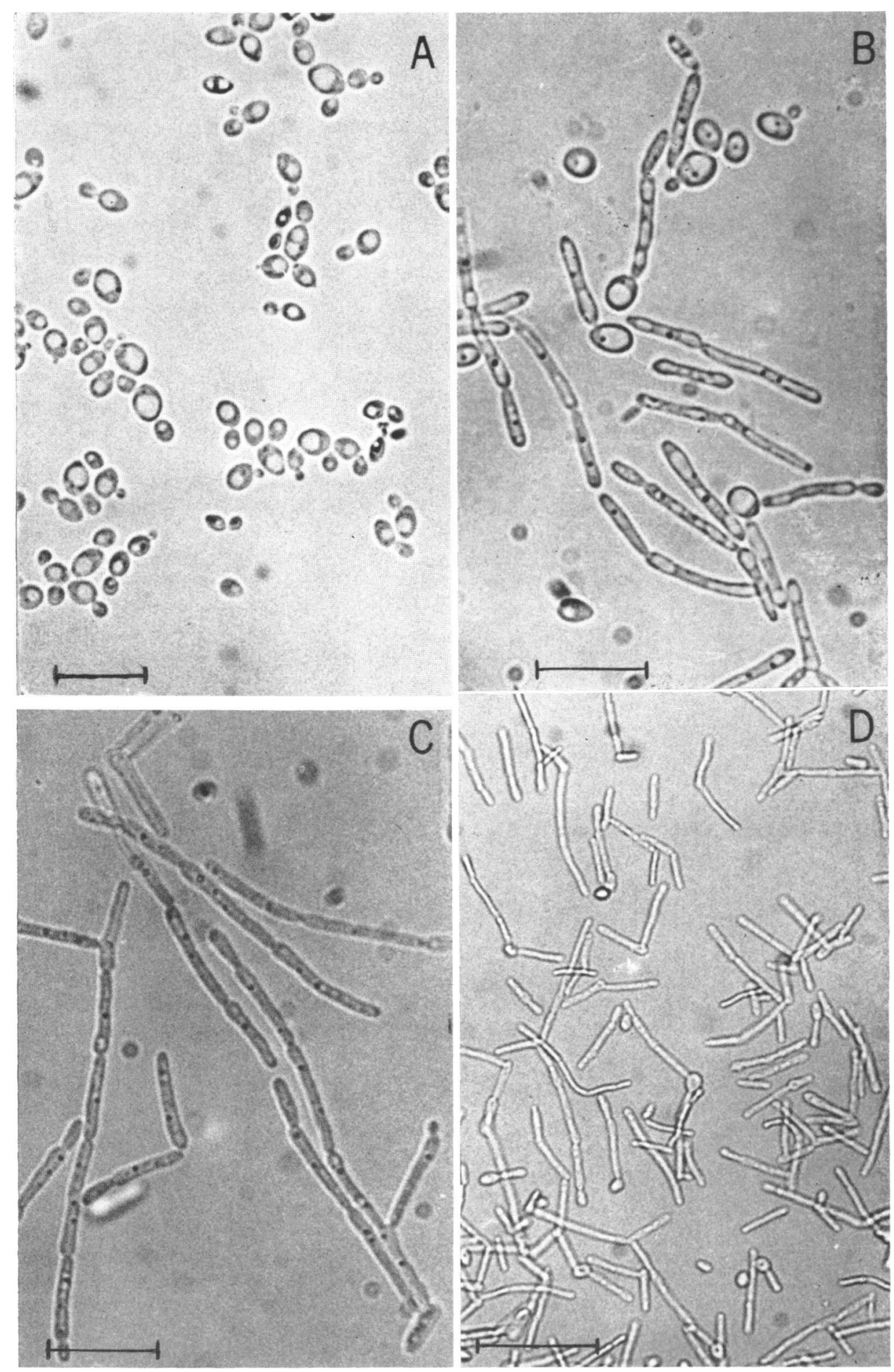

FIG. 1. Elongation of cells of Hansenula schneggii after growth in L-tryptophan. Indicator line for plates $A, B$, and $C$ is equivalent to $20 \mu$; that for plate $D$ is equivalent to $40 \mu .(A)$ Cells of $H$. schneggii grown in YM broth medium for $48 \mathrm{hr}$. (B) Elongated buds arising from vegetative cells grown in tryptophan defined medium for 48 $\mathrm{hr}$. (C) Elongated cells arising from elongated cells cultured in tryptophan medium for $72 \mathrm{hr}$. (D) Round buds arising from elongated cells grown in tryptophan medium for 5 days. 


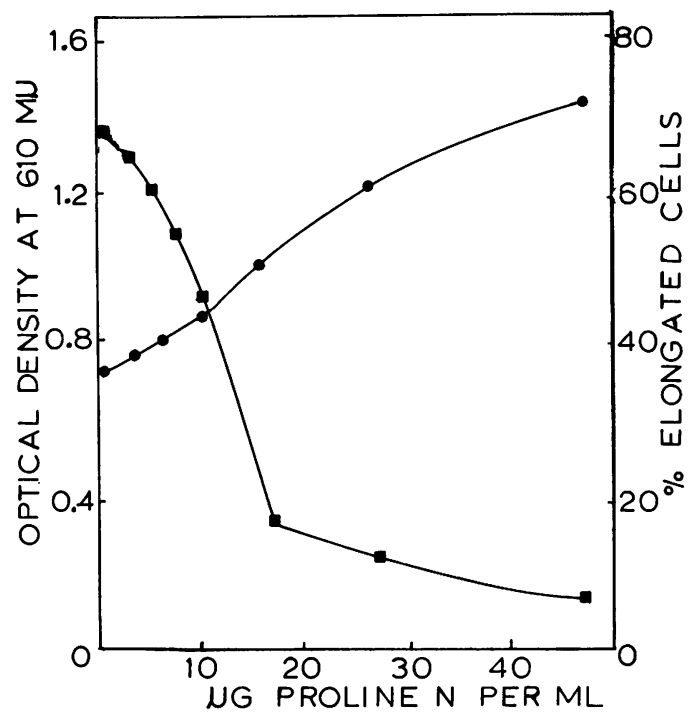

FIG. 2. Decrease in percentage of elongated cells and increase in growth as the amount of proline was increased in a series of eight experiments. In each experiment, there was an initial concentration of $500 \mu \mathrm{g}$ of glucose and $150 \mu \mathrm{g}$ of tryptophan $\mathrm{N}$ per $\mathrm{ml}$. The amounts of proline added for each experiment are indicated as abscissas. Amount of growth and percentage of elongated cells were determined after $72 \mathrm{hr}$ of incubation at $28 \mathrm{C}$ on a shaker. Symbols: $\mathrm{O}$, growth of cells: $\square$, percentage of elongated cells.

of elongated cells: $12 \%$ at $40 \mathrm{hr}$ and $20 \%$ at $55 \mathrm{hr}$.

Some biochemical changes of cultures with an inoculum of depleted cells during the first $5 \mathrm{hr}$ of incubation in TG and AG media showed that, at the end of the 5-hr period, the TG-grown cells had a $10 \%$ loss of protein and RNA, whereas the AG-grown cells had a $15 \%$ increase in protein and RNA; the DNA content for the TGgrown cells decreased $10 \%$; that for AG-grown cells remained the same.

To determine whether elongated cells released a compound which induced other cells to be elongated, cells were inoculated into a membrane filtrate of "used" TG medium in which elongated cells had been grown. This TG medium was modified to contain only $50 \mu \mathrm{g}$ of tryptophan $\mathrm{N}$ rather than $300 \mu \mathrm{g}$ of $\mathrm{N}$ per $\mathrm{ml}$, so that there would be no excess of tryptophan at the end of the incubation period. There was some growth in the filtrate, but when glucose was added there was additional growth until all the soluble nitrogen released by growing cells in the medium prior to filtration was utilized. The cells which grew in the filtrate under these conditions were ellipsoidal. However, when $100 \mu \mathrm{g}$ of tryptophan $\mathrm{N}$ per ml was added to the mixture, additional growth occurred, but cells which grew thereafter were mostly

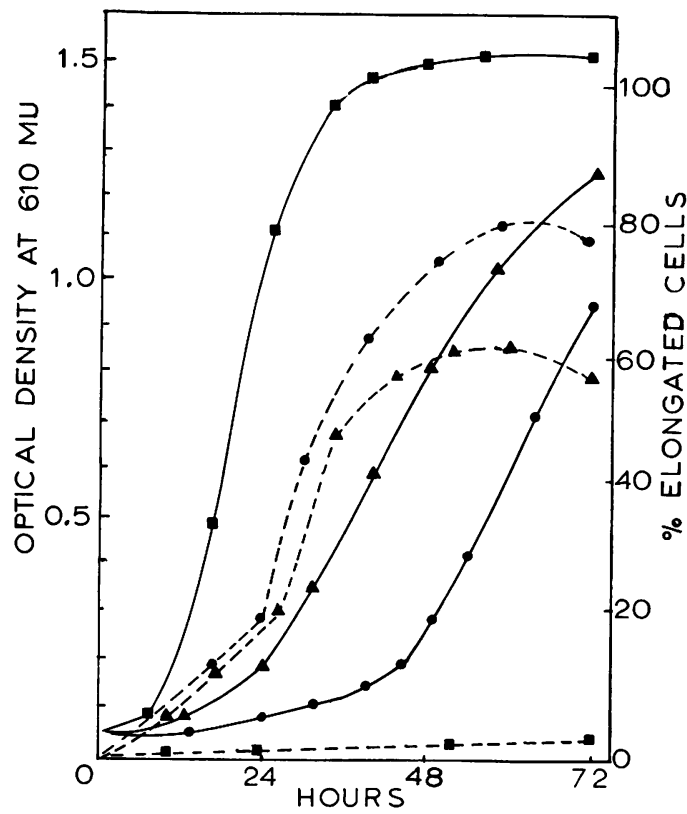

Fig. 3. Effect of the inoculum type (depleted cells or nondepleted cells) upon growth and percentage of elongated cells when cultured in media with tryptophan or ammonium sulfate nitrogen. Glucose $(2 \%)$ was the carbon source in defined medium. Cells were cultured on a shaker at 28 C. Symbols: $\square$, ammonium sulfate (150 $\mu \mathrm{g}$ of $N$ per $\mathrm{ml}) ; \Delta$, tryptophan $(150 \mu \mathrm{g}$ of $N$ per $\mathrm{ml}$ ) with inoculum of nondepleted cells; 1 tryptophan (150 $\mathrm{g}$ of $N$ per $\mathrm{ml}$ ) with inoculum of depleted cells. Solid lines indicate growth and dashed lines indicate the percentage of elongated cells.

elongated. Therefore, elongated cells did not release substances which induce other cells to be elongated in the absence of tryptophan (Table 1).

Microscopic observations on the budding process showed that elongated buds were formed from the ellipsoidal parents. Usually only one bud arose from each parent; sometimes there were two. Each bud developed into an elongated cell, which in turn formed an elongated bud; by this method, chains of several elongated cells were formed. In cultures incubated in the TG medium for 5 days, nearly all the cells were elongated. Some of these elongated cells formed spherical buds, usually one, but sometimes two or three (Fig. 1D).

The isolation of many colonies on streaked plates, and their succeeding cultures in the TG medium, never gave a culture in which a large majority of the cells did not become elongated. Cultivation of single-cell isolates of both elongated and ellipsoidal forms gave micro-colonies which, when transferred to the tryptophan medium, produced largely elongated cells.

Effects of compounds related to tryptophan on 
TABLE 1. Growth and morphology of Hansenula schneggii in filtrate of "used" modified tryptophan-glucose-salts medium

\begin{tabular}{|c|c|c|c|}
\hline \multirow{2}{*}{ Growth medium } & \multicolumn{2}{|c|}{ Growth (OD units) } & \multirow{2}{*}{$\begin{array}{l}\text { Degree of mor- } \\
\text { phological change } \\
\text { (as percentage } \\
\text { of elongated cells) }\end{array}$} \\
\hline & $0 \mathrm{hr}$ & $48 \mathrm{hr}$ & \\
\hline Filtrate only ${ }^{a}$ & 0.018 & 0.162 & None \\
\hline $\begin{array}{c}\text { Filtrate }+ \text { glu- } \\
\text { cose } \ldots \ldots \ldots \ldots\end{array}$ & 0.018 & 0.443 & \\
\hline $\begin{array}{c}\text { Filtrate }+ \text { tryp- } \\
\text { tophan }+ \text { glu- } \\
\text { cose } \ldots \ldots\end{array}$ & 0.018 & 0.620 & 58 \\
\hline
\end{tabular}

${ }^{a}$ Filtrate refers to liquid collected from $0.45-\mu$ porosity membrane filter in which cells had been cultured for 5 days and percentage of elongated cells was 80 . Tryptophan concentration in medium pior to growth of cells, $50 \mu \mathrm{g}$ of $\mathrm{N}$ per ml; concentration after growth, essentially zero. Ninhydrin-positive substances (amino acids) were present in the filtrate.

elongation. Several compounds related to tryptophan were added to TG or glucose-salts basal media to determine their relationship to growth and percentage of elongated cells. Kynurenine was the only compound which caused elongation in a high percentage of the cells.

Microscopic observations of cells during the different stages of the growth curve revealed that cells cultured in kynurenine formed elongated buds somewhat earlier than did those grown in tryptophan. Furthermore, the size of these cells was smaller than those grown in tryptophan, the respective sizes being: 2 to $5 \mu$ by 10 to $12 \mu$ as compared with 1.5 to $3 \mu$ by 15 to $25 \mu$. Of the other compounds tested, only tryptamine, indole plus serine, and indole plus ammonium sulfate provided good growth; in none of these was there an appreciable number of elongated cells (Table 2).

Other environmental factors which influence elongation. The effects of the following variables upon the percentage of elongated cells were studied: successive sequential transfers into tryptophan media, type of carbon source, $p \mathrm{H}$ during growth, presence and absence of oxygen during growth, and addition of sulfhydryl compounds.

It was of interest to determine whether successive transfers into tryptophan media would produce a culture in which all the cells were elongated. These studies were performed with nondepleted cells as an inoculum. After five sequential transfers into other tubes of TG medium, the maximal number of elongated cells ever attained was $90 \%$. The same maximal percentage was attained for sequential transfers starting with an
TABLE 2. Growth and percentage of elongated cells in tryptophan-related compounds

\begin{tabular}{|c|c|c|}
\hline Compound(s) added to basal medium ${ }^{a}$ & $\begin{array}{c}\text { Growth } \\
\text { at } 60 \\
\text { hr }\end{array}$ & $\begin{array}{l}\text { Percentage } \\
\text { of elongated } \\
\text { cells }\end{array}$ \\
\hline None. & 0.018 & 1 \\
\hline Tryptophan. & 0.620 & 85 \\
\hline Kynurenine. & 0.685 & 70 \\
\hline Kynurenine + tryptophan & 0.720 & 79 \\
\hline Tryptamine $\cdot \mathbf{H C l} \ldots . .$. & 0.620 & 4 \\
\hline $\begin{array}{c}\text { Tryptamine.HCl }+ \text { trypto- } \\
\text { phan } \ldots \ldots \ldots \ldots \ldots \ldots \ldots \ldots\end{array}$ & 0.659 & 40 \\
\hline Anthranilic acid ... & 0.027 & 一 \\
\hline $\begin{array}{c}\text { Anthranilic acid }+ \text { trypto- } \\
\text { phan } \ldots \ldots \ldots \ldots \ldots \ldots \ldots\end{array}$ & 0.851 & 73 \\
\hline $\begin{array}{c}\text { Anthranilic acid }+ \text { ammo- } \\
\text { nium sulfate } \ldots \ldots \ldots \ldots \ldots\end{array}$ & 0.553 & 1 \\
\hline Nicotinic acid. & 0.045 & 一 \\
\hline Nicotinic acid + tryptophan & 0.602 & 88 \\
\hline $\begin{array}{c}\text { Nicotinic acid }+ \text { ammonium } \\
\text { sulfate } \ldots \ldots \ldots \ldots \ldots \ldots \ldots\end{array}$ & 0.700 & 1 \\
\hline Indole acetic acid ....... & 0.027 & - \\
\hline $\begin{array}{l}\text { Indole acetic acid }+ \text { trypto- } \\
\text { phan } \ldots \ldots \ldots \ldots \ldots \ldots \ldots\end{array}$ & 0.018 & 一 \\
\hline Indole. . & 0.027 & - \\
\hline Indole + serine. & 0.980 & 5 \\
\hline Indole + ammonium sulfate & 0.679 & 1 \\
\hline Indole propionic acid.. & 0.055 & 一 \\
\hline Indole lactic acid. & 0.045 & - \\
\hline Hydroxytryptophan & 0.085 & 一 \\
\hline Methyltryptophan & 0.143 & 1 \\
\hline $\begin{array}{r}\text { Serotonin } \\
\text { indolol }) \ldots \ldots \ldots \ldots \ldots \ldots \ldots\end{array}$ & 0.260 & 2 \\
\hline
\end{tabular}

a Compounds were added at a concentration of $300 \mu \mathrm{g}$ of $\mathrm{N}$ per $\mathrm{ml}$; if two compounds were added the concentration of each was $150 \mu \mathrm{g}$. Basal medium was glucose-salts medium. Depleted cells were used as an inoculum.

inoculum of depleted cells. When cells from any of the cultures grown in tryptophan were transferred into media with other nitrogen sources, such as casein hydrolysate, ammonium sulfate, or other amino acids, the percentage of elongation was essentially zero.

Sixteen carbon sources were tested for growth with tryptophan. Of these, D-glucose, D-mannose, maltose, melezitose, and $\alpha$-methyl glucoside supported good growth (an OD of about 1.0) with 69 to $78 \%$ elongated cells. Two alcohols, erythritol and mannitol, gave good growth, but the number of elongated cells was only about $50 \%$. The other carbon sources tested gave varying and lesser amounts of growth and percentages of elongated cells. These results are given in Table 3.

The effects of different $p \mathrm{H}$ values upon growth and elongation are shown in Table 4. The amount of growth was the same over a $p \mathrm{H}$ range of 4.0 to 8.0 ; however, the percentage of elongated 
TABLE 3. Response of Hansenula schneggii to different carbon sources ${ }^{a}$

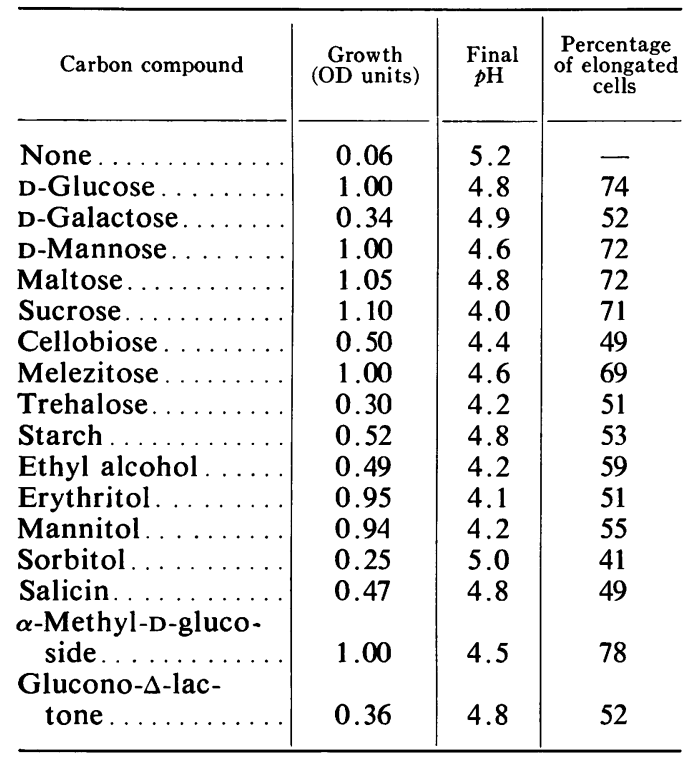

${ }^{a}$ Tryptophan in concentration of $150 \mu \mathrm{g}$ of $\mathrm{N}$ per $\mathrm{ml}$ was the nitrogen source. Determinations were made after $72 \mathrm{hr}$ of incubation at $28 \mathrm{C}$. Carbon compounds were filter-sterilized and added so the final concentration was $5 \mathrm{mg} / \mathrm{ml}$.

TABLE 4. Effect of pH upon growth and percentage of elongated cells of Hansenula schneggii

\begin{tabular}{r|c|c|c|c|c|c}
\hline $\begin{array}{c}\text { Initial } \\
p \mathrm{H} \text { of } \\
\text { me- } \\
\text { dium }^{a}\end{array}$ & \multicolumn{2}{|c|}{ Growth (optical density units) } & \multicolumn{2}{|c|}{$\begin{array}{c}\text { Final } \\
p \mathrm{H}\end{array}$} & $\begin{array}{c}\text { 24 hr } \\
\text { Percentage }\end{array}$ & $\begin{array}{c}\text { P8 hr } \\
\text { of elongated } \\
\text { cells after } \\
72 \mathrm{hr}\end{array}$ \\
\hline 2.0 & 0.03 & 0.03 & 0.03 & 0.03 & 2.0 & - \\
3.0 & 0.03 & 0.03 & 0.04 & 0.07 & 3.0 & - \\
4.0 & 0.03 & 0.10 & 0.60 & 0.60 & 4.5 & 73 \\
5.0 & 0.03 & 0.16 & 0.55 & 0.54 & 4.5 & 75 \\
6.0 & 0.04 & 0.17 & 0.57 & 0.55 & 5.0 & 51 \\
7.0 & 0.04 & 0.19 & 0.62 & 0.60 & 6.5 & 42 \\
8.0 & 0.04 & 0.15 & 0.51 & 0.51 & 6.5 & 21 \\
9.0 & 0.04 & 0.16 & 0.41 & 0.46 & 6.5 & 5 \\
10.0 & 0.03 & 0.07 & 0.07 & 0.09 & 10.5 & - \\
\hline
\end{tabular}

${ }^{a}$ Medium contained $50 \mu \mathrm{g}$ of tryptophan $\mathrm{N}$ and $1 \mathrm{mg}$ of glucose per $\mathrm{ml}$.

cells became less as the initial $p H$ of the culture was increased above 5.0.

The following methods were employed to determine the effect of aeration upon the percentage of elongated cells: growing cells on a shaker, bubbling nitrogen into the tubes, and culturing under sterile mineral oil. With tryptophan as a nitrogen source, there was very little growth or elongation in the absence of air. Shaken as compared with stationary cultures gave more growth and a higher percentage of elongated cells; direct aeration gave essentially the same results as growth on the shaker. Culturing under mineral oil or under nitrogen prevented growth beyond an optical density reading of about 0.20 with essentially no elongation.

Nickerson and Falcone (17) reported that the divisionless strain of Candida albicans grew as a typical budding yeast in the absence of added sulfur compounds, but when grown in the presence of sulfur compounds, supplied either as methionine or sulfate, the cells became greatly elongated into filaments. $H$. schneggii cells grown in methionine gave good growth (OD of 1.0) but no cellular elongation. With cystine, the growth was poor (OD of 0.30 ) and the percentage of elongated cells was 14; there was no growth with cysteine. A sulfhydryl compound, 2-mercaptoethanol, when added to the tryptophan medium at a concentration greater than $5 \times 10^{-5}$ $M$ inhibited growth. At the $5 \times 10^{-5} \mathrm{M}$ concentration, growth of cells was only one-third that in the absence of the sulfhydryl compound, and the cells produced were mostly ellipsoidal and were smaller. Growth of cells in tryptophan medium with $10^{-5}$ and $10^{-6} \mathrm{M}$ concentrations of $p$-chloromercuribenzoate, a compound reported to combine with sulfhydryl bonds, gave good growth and the same percentage of elongation as in its absence.

Differences in some cell wall components. Nickerson and his colleagues in their various studies of yeast morphogenesis have considered some of the cell wall fractions to be principal factors responsible for differences in cell shape. Our studies of cell wall components of ellipsoidal and elongated yeasts have shown quantitative differences in the two types with respect to the following compounds: mannan, protein, lipid, and phosphorus (Table 5).

\section{DisCUSSION}

Growth of $H$. schneggii with tryptophan or kynurenine as a nitrogen source induced elongation of cells. With respect to the growth cycle, cells cultured in kynurenine elongated earlier than cells grown in tryptophan. This suggests that kynurenine may be the true inducer of elongation; however, kynurenine-grown cells were only about one-half the length of cells grown in tryptophan. Other compounds structurally related to tryptophan did not induce elongation, even if they supported growth. A few amino acids caused about $15 \%$ of the cells to be elongated. These elongation inducers may interfere with some aspects of cell division.

The results of the cell wall analyses suggest, as one hypothesis, that these inducers were 
TABLE 5. Quantitative comparison of some components of elongated and ellipsoidal cell walls of Hansenula schneggii ${ }^{a}$

\begin{tabular}{|c|c|c|c|c|c|c|}
\hline \multirow{2}{*}{ Cell wall component } & \multicolumn{3}{|c|}{ Elongated cells } & \multicolumn{3}{|c|}{ Ellipsoidal cells } \\
\hline & $\begin{array}{c}\text { Amt of cell wall } \\
\text { analyzed } \\
(\mathrm{mg}, \text { dry } w t)\end{array}$ & $\begin{array}{c}\text { Cell wall } \\
\text { component } \\
\text { determined }(\mathrm{mg})\end{array}$ & $\begin{array}{l}\text { Percentage of } \\
\text { component in } \\
\text { cell wall }\end{array}$ & $\begin{array}{c}\text { Amt of cell wall } \\
\text { analyzed } \\
(\mathrm{mg}, \text { dry } w \mathrm{t})\end{array}$ & $\begin{array}{c}\text { Cell wall } \\
\text { component } \\
\text { determined (mg) }\end{array}$ & $\begin{array}{c}\text { Percentage of } \\
\text { component in } \\
\text { cell wall }\end{array}$ \\
\hline Mannan.... & 100 & 33.4 & 33.4 & 100 & 12.5 & 12.5 \\
\hline Protein. . & 11.7 & 1.59 & 13.6 & 14.7 & 3.56 & 24.4 \\
\hline Total lipids. & 58.0 & 12.4 & 20.2 & 141.0 & 18.6 & 13.2 \\
\hline Bound lipids. & 58.0 & 3.4 & 6.4 & 141.0 & 8.9 & 6.3 \\
\hline Free lipids... & 58.0 & 8.0 & 13.8 & 141.0 & 9.7 & 6.9 \\
\hline Phosphorus... & 50.0 & 0.18 & 0.36 & 50.0 & 0.09 & 0.18 \\
\hline
\end{tabular}

a Elongated cells were grown in glucose-tryptophan; ellipsoidal cells were grown in glucoseammonium sulfate.

responsible for a partial diversion of fructose-6phosphate into mannose and mannan. The presence of less protein in cell walls of elongated versus ellipsoidal cells suggests that there was not an increase in protein to correspond with the increase in mannan. As the amount of bound lipids was the same for the two cell types, lipids are probably not directly related to cell wall changes associated with elongation. The increase in the concentration of free lipids for the elongated cells is probably associated with a disturbance of the optimal or normal ratio of carbon to readily available nitrogen, as tryptophan is not used if other more rapidly utilizable nitrogen is available.

The fact that kynurenine supported growth and 5-hydroxytryptamine did not is presumptive evidence that tryptophan is metabolized via the kynurenine pathway. Inability of serine and indole to induce elongation, even though good growth was supported, indicates an absence of the enzyme tryptophan synthetase in this organism. Inhibition of growth by indole acetic acid shows that elongation was not due to a common plant auxin.

From these studies, it is apparent that elongation is produced by the formation and growth of elongated buds and not by direct transformation of ellipsoidal cells into elongated ones. If nitrogen sources other than tryptophan or kynurenine were available to the cells-by the addition of other nitrogen sources, the use of an inoculum of nondepleted cells, or the release of available nitrogen in later stages of the growth cycle-the formation of elongated buds ceased in direct proportion to the amount of additional nitrogen source available. Exhaustive attempts to secure a culture in which all the cells were elongated by continued transfer to fresh tryptophan media have been negative; the highest percentage of elongated cells attained was about $90 \%$. Studies with isolated cells which developed into micro- colonies have never given a culture in which the ellipsoidal or the elongated cell shape persisted when cultured in tryptophan. These observations indicate that elongation of cells by growth in tryptophan nitrogen was due to environmental factors rather than mutation. The fact that cells grown in filtrates of a tryptophan medium, in which elongated cells had been grown, were ellipsoidal indicates that the release by cells of either toxic products or specific inducers into the medium was not the primary cause of elongation.

Several amino acids, such as tryptophan, phenylalanine, and tyrosine, which induced some elongation belong to the aromatic family of amino acids; but other amino acids, such as threonine, cystine and histidine, which caused some elongation belong to other amino acid families (1). Thus, compounds not directly related to the aromatic ring must be responsible for induction of elongation.

Our observations are in agreement with those of other workers in the field of fungal morphogenesis, to wit, that the cells in a population are never $100 \%$ converted to the specific shape in question in response to nutritional or environmental factors $(9,13,24,27)$.

\section{ACKNOWLEDGMENTS}

This investigation was supported by Public Health Service grant PHS GM 11643 from the National Institutes of Health.

We thank L. J. Wickerham for the cultures of Hansenula yeasts.

\section{LiteRATURE CITED}

1. Abelson, P. H., AND H. J. Vogel. 1955. Amino acid bicsynthesis in Torulopsis utilis and Neurospora crassa. J. Biol. Chem. 213:355-364.

2. Al-DOORY, Y., AND H. W. LARSH. 1962. Quantitative studies of total lipids of pathogenic fungi. Appl. Microbiol. 10:492-495.

3. Bartnicki-GarCia, S. 1963. Symposium on bio- 
chemical cases of morphogenesis in fungi. III. Mold-yeast dimorphism of Mucor. Bacteriol. Rev. 27:293-304.

4. Burton, K. 1956. A study of the conditions and mechanism of the diphenylamine reaction for the colorimetric estimation of deoxyribonucleic acid. Biochem. J. 62:315-323.

5. Dimler, R. J., W. C. Schaeffer, C. B. Wise, AND C. E. Rist. 1952. Quantitative paper chromatography of D-glucose and its oligosaccharides. Anal. Chem. 24:1411-1414.

6. EATON, N. R. 1960. Endogenous respiration of yeast. I. The endogenous substrate. Arch. Biochem. Biophys. 88:17-25.

7. Falcone, G., and W. J. Nickerson. 1956. Cell wall mannan-protein of bakers' yeast. Science 124:272-282.

8. Fiske, C. H., and Y. SubbaRow. 1929. Phosphorus compounds of muscle and liver. Science 70:381-382.

9. Grula, E. A., and M. M. Grula. 1962. Cell division in a species of Erwinia. III. Reversal of inhibition of cell division caused by D-amino acids, penicillin, and ultraviolet light. J. Bacteriol. 83:981-988.

10. Kabat, E. A., and M. M. Mayer. 1948. Experimental immunochemistry. Charles C Thomas, Publisher, Springfield, Ill.

11. Kemmerer, G., AND L. T. HaLlet. 1927. Improved micro-Kjeldahl ammonia distillation apparatus. Ind. Eng. Chem. 19:1295-1296.

12. Lowry, O. H., N. J. Rosebrough, A. L. FarR, AND R. J. Randall. 1951. Protein measurement with the Folin phenol reagent. J. Biol. Chem. 193:265-275.

13. Maclean, F. I., ANd R. J. Munson. 1961. Some environmental factors affecting the length of Escherichia coli organisms in continuous cultures. J. Gen. Microbiol. 25:17-27.

14. MeYer, H. 1957. The ninhydrin reaction and its analytical applications. Biochem. J. 67:333340.

15. Nickerson, W. J. 1963. Symposium on biochemical bases of morphogenesis in fungi. IV. Molecular bases of form in yeasts. Bacteriol. Rev. 27:305-324.

16. Nickerson, W. J., AND C. W. Chung. 1954. Genetic block in the cellular division mechanism of a morphological mutant of a yeast. Am. J. Bot. 41:114-120.

17. Nickerson, W. J., AND G. Falcone. 1959. Function of protein disulfide reductase in cellular division of yeasts, p. 409-424. In R. Benesch [ed.], Sulfur in proteins. Academic Press, Inc., New York.

18. PARTRIDGe, S. M. 1948. Filter-paper partition chromatography of sugars. I. General description and application to the qualitative analysis of sugars in apple juice, egg white and foetal blood of sheep. Biochem. J. 42:238-250.

19. Piez, K. A., F. Irreverre, and H. L. Wolff. 1956. The separation and determination of cyclic amino acids. J. Biol. Chem. 223:687697.

20. Roberts, R. B., P. H. Abelson, D. B. Cowie, E. T. Bolton, AND R. J. Britten. 1955. Studies of biosynthesis in Escherichia coli. Carnegie Inst. Wash. Publ. 607.

21. Roelofsen, P. A. 1953. Yeast mannan, a cell wall constituent of baker's yeast. Biochim. Biophys. Acta 10:447-478.

22. Rosen, H. 1957. A modified ninhydrin colorimetric analysis. Arch. Biochem. Biophys. 67: 10-15.

23. SChNeider, W. C. 1945. Phosphorus compounds in animal tissues. I. Extraction and estimation of deoxypentose nucleic acid and pentose nucleic acid. J. Biol. Chem. 161 :295-303.

24. SentheShanmuganathan, S., and W. J. NickerSON. 1962. Nutritional control of cellular forms in Trigonopsis variabilis. J. Gen. Microbiol. 27:437-449.

25. SentheShanmuganathan, S., and W. J. NickerSON. 1962. Composition of cells and cell walls of triangular and ellipsoidal forms of Trigonopsis variabilis. J. Gen. Microbiol. 27:451-464.

26. Spies, J. R., and D. C. Chambers. 1948. Chemical determination of tryptophan, p-diamino benzaldehyde and sodium nitrate in sulfuric acid solution. Anal. Chem. 20:30-39.

27. Takada, H., H. Morishita, and T. Yagi. 1963. Evidence for dimorphic character by Endomycopsis fibuliger. Trans. Mycol. Soc. Japan 4:126-130.

28. WiCKerhaM, L. J. 1946. A critical evaluation of the nitrogen assimilation tests commonly used in the classification of yeasts. J. Bacteriol. 52: 293-301.

29. Yanagishima, N. 1962. Dimorphism phenomenon in respiration-deficient yeast. J. Biol. Osaka City Univ. 12:47-59.

30. Yanagishima, N., AND Y. Masuda. 1964. RNA functional in auxin action to elongate yeast cells. Plant Cell Physiol. 5:369-372. 